\title{
An Assessment of Global Forest Change Datasets for National Forest Monitoring and Reporting
}

\author{
Nikolaos Galiatsatos ${ }^{1}$, Daniel N.M. Donoghue ${ }^{2, *} \mathbb{0}$, Pete Watt ${ }^{3}$, Pradeepa Bholanath ${ }^{4}$, \\ Jeffrey Pickering ${ }^{5}$, Matthew C. Hansen ${ }^{5}$ and Abu R.J. Mahmood ${ }^{6}$ \\ 1 Royal School of Military Survey, Geospatial Exploitation Wing, Thatcham RG18 9TP, UK; ngaliats@gmail.com \\ 2 Department of Geography, Science Laboratories, Durham University, Durham DH1 3LE, UK \\ 3 Resource Mapping and Climate Change, Indufor Asia Pacific Ltd, 1143 Auckland City, New Zealand; \\ pete.watt@indufor-ap.com \\ 4 Guyana Forestry Commission, Planning and Development Division, 1 Water Street, Kingston, Georgetown, \\ Guyana; project.coordinator@forestry.gov.gy \\ 5 Department of Geographical Sciences, University of Maryland, College Park, MD 20742, USA; \\ jeffreyp@umd.edu (J.P.); mhansen@umd.edu (M.C.H.) \\ 6 Natural Resource Management Group, Food and Agriculture Organization of the United Nations, \\ Regional Office for Asia and the Pacific, Bangkok 10200, Thailand; ifescu@gmail.com \\ * Correspondence: danny.donoghue@durham.ac.uk; Tel.: +44-0191-334-1867
}

Received: 5 May 2020; Accepted: 15 May 2020; Published: 2 June 2020

\begin{abstract}
Global Forest Change datasets have the potential to assist countries with national forest measuring, reporting and verification (MRV) requirements. This paper assesses the accuracy of the Global Forest Change data against nationally derived forest change data by comparing the forest loss estimates from the global data with the equivalent data from Guyana for the period 2001-2017. To perform a meaningful comparison between these two datasets, the initial year 2000 forest state needs first to be matched to the definition of forest land cover appropriate to a local national setting. In Guyana, the default definition of $30 \%$ tree cover overestimates forest area is by 483,000 ha $(18.15 \%)$. However, by using a tree canopy cover (i.e., density of tree canopy coverage metric) threshold of $94 \%$, a close match between the Guyana-MRV non-forest area and the Global Forest Change dataset is achieved with a difference of only 24,210 ha $(0.91 \%)$ between the two maps. A complimentary analysis using a two-stage stratified random sampling design showed the $94 \%$ tree canopy cover threshold gave a close correspondence $\left(R^{2}=0.98\right)$ with the Guyana-MRV data, while the Global Forest Change default setting of $30 \%$ tree canopy cover threshold gave a poorer fit $\left(R^{2}=0.91\right)$. Having aligned the definitions of forest for the Global Forest Change and the Guyana-MRV products for the year 2000, we show that over the period 2001-2017 the Global Forest Change data yielded a 99.34\% overall Correspondence with the reference data and a 94.35\% Producer's Accuracy. The Guyana-MRV data yielded a 99.36\% overall Correspondence with the reference data and a 95.94\% Producer's Accuracy. A year-by-year analysis of change from 2001-2017 shows that in some years, the Global Forest Change dataset underestimates change, and in other years, such as 2016 and 2017, change is detected that is not forest loss or gain, hence the apparent overestimation. The conclusion is that, when suitably calibrated for percentage tree cover, the Global Forest Change datasets give a good first approximation of forest loss (and, probably, gains). However, in countries with large areas of forest cover and low levels of deforestation, these data should not be relied upon to provide a precise annual loss/gain or rate of change estimate for audit purposes without using independent high-quality reference data.
\end{abstract}

Keywords: REDD+; land cover; earth observation; global forest change; monitoring reporting and verification; MRVS; deforestation 


\section{Introduction}

It is estimated that $12 \%-20 \%$ of global greenhouse gas emissions between 1990 and 2000 were from forest loss, primarily in tropical regions [1]. Estimations of $\mathrm{CO}_{2}$ emissions and removals show large differences and high levels of uncertainty. For example, in tropical regions, the Joint Research Centre of the European Commission estimated the annual carbon loss during 2000-2010 as 0.81 to $1.2410^{9} \mathrm{tC}$ year $^{-1}$ using a systematic sample design based on $30 \mathrm{~m}$ resolution satellite imagery [2], while Tyukavina et al. [3] estimated gross carbon emissions as 1.22 and $1.3810^{9} \mathrm{tC}$ year $^{-1}$ for 2000-2012 based on a random sample-based estimate stratified using the University of Maryland Global Forest Change dataset. Federici et al. [4] estimated a global forest-related emissions value of $1.1010^{9} \mathrm{tC}$ year $^{-1}$ for forest-related emissions from 1991 to 2015 based on modelling of country data derived from the Food and Agricultural Organization of the United Nations (FAO). This compares favourably with a study by Le Quéré et al. that quantifies all major fluxes of the global carbon cycle and reports an annual emission value of $1.0 \pm 0.510^{9} \mathrm{tC}$ year $^{-1}$ for land use change between 2000 to 2014 [5]. The reader should note the large uncertainty attached to the estimates of annual carbon loss and of annual global emissions; the differences in quantitative estimates are essentially due to the quantity, quality and global availability of reliable land cover change data, which are the focus of this paper.

The Conference of the Parties (e.g., Decision 4/CP.15 [6]; Decision 1/CP.16 [7]; Decision 12/CP.17 [8]; Decision 1/CP.21 [9]) of the United Nations Framework Convention on Climate Change (UNFCCC) requests countries to report reference greenhouse gas emission levels and/or forest change reference levels using consistent and verifiable methodologies and common metrics so these can be assessed by the Intergovernmental Panel on Climate Change (IPCC) [9]. This involves individual countries developing measurement, reporting and verification (MRV) systems able to generate detailed annual reports on national land use change (activity data) and related $\mathrm{CO}_{2}$ emission factors (EF) in an IPCC format for audit by the UNFCCC-Reduced Emission from Deforestation and forest Degradation plus (REDD+). The audit function presents considerable challenges for many developing countries that lack national forest inventories, access to frequently-updated national land cover maps, technical expertise and resources $[10,11]$. Guyana has been a first mover on REDD+ and MRV system develop even before all decisions were made by the Conference of the Parties (COP) process at UNFCCC as the Guyana Norway Bilateral Cooperation on Forest and Climate started in 2009/2010 and required an MRVS to be developed with the guidance that was available the time and then continuously improved with the building of capacity locally, and the finalising of decisions at the international level.

The FAO global Forest Resources Assessments (FRA) statistics are valuable for regional and global studies of the carbon cycle [2] and deforestation [12]. However, at a country-level, aspects of the FRA's statistics have been criticised by Grainger [10], mainly due to the lack of comparable long-term trend data [13], and inconsistencies in the definition of what should be considered forest land cover [14]. Good practice guidelines in [15] and [16] recognise the limitations of the FRA data and recommend the use of satellite remote sensing, as it provides low cost and reliable data on land cover change [11]. Decision 4/CP.15 recognised that robust and transparent national forest monitoring systems will use a combination of remote sensing and ground-based forest carbon inventory approaches to generate a repeatable and consistent survey of large areas at a relatively low unit cost [6].

The first attempts to report forest cover change used ground surveys and highly generalized biogeographic maps [17-19]. Subsequent advances in sensor quality and data availability resulted in large area and global land cover mapping using a range of sensors such as AVHRR, MODIS, SPOT-VEGETATION, MERIS and Landsat [20-26].

One of the main catalysts that led to the improvement of land cover monitoring was the change in the Landsat Data Distribution Policy to allow free access to satellite data. This change led to the creation of $30 \mathrm{~m}$ resolution global (Table 1) and regional [27-29] land cover maps [30]. Of all the different global surveys summarized in Table 1, Hansen et al. [31] reported the highest accuracy. Multi-epoch map products quickly followed which for the first time allowed the estimation of forest cover change at global to national-scale using a globally consistent methodology [2,31-34]. 
Table 1. Global forest mapping products derived mainly from Landsat imagery.

\begin{tabular}{cccc}
\hline Product & Validation & Accuracy & Ref. \\
\hline RSS 2010 & Expert validation & $77 \%-81 \%$ & {$[35]$} \\
\hline FROM-GLC & $\begin{array}{c}\text { MODIS-EVI and } \\
\text { Google Earth }\end{array}$ & $65 \%$ & {$[36]$} \\
\hline Global Forest Change & $\begin{array}{c}\text { Landsat, MODIS, Google Earth, } \\
\text { GLAS-ICEsat }\end{array}$ & $99.6 \%$ & {$[31]$} \\
\hline $\begin{array}{c}\text { Continuous fields of } \\
\text { tree cover }\end{array}$ & LiDAR & $\begin{array}{c}\text { Root mean square error: 16.8\% } \\
\text { (MODIS) and 17.4\% (Landsat) }\end{array}$ & {$[37]$} \\
\hline $\begin{array}{c}\text { Global Land Survey } \\
(1990-2000)\end{array}$ & Landsat & $88 \%$ & {$[38]$} \\
\hline
\end{tabular}

In spite of the availability of $30 \mathrm{~m}$ resolution satellite datasets, operational national-level MRV systems have been slow to evolve within the context of REDD+. The Global Forest Change datasets are available from the internet (www.globalforestwatch.org) and can easily be integrated into any national or localised MRV system [31]. Independent studies of forest change from 2000 to 2010 find broad agreement with the Global Forest Change datasets for humid tropical countries [25,36]. In this context, it is important to assess whether the global maps are sufficiently accurate to be used to establish initial reference levels, and to quantify forest loss or gain at a national-scale.

Guyana, like many countries that have established an MRV system, or those starting on that track, have an interest in understanding the value of the Global Forest Change datasets. For instance, can these data provide a useful and reliable source of information that can be used directly, or adapted, to satisfy national reporting requirements? Guyana provides a good test case as it has a well-established MRV system and has created wall-to-wall national maps of deforestation and forest degradation spanning from 1990 to 2017. Guyana's MRV data are in turn validated with probability-based accuracy assessments using independent high-quality reference data, an output that lends itself to a quantitative assessment of the Global Forest Change datasets.

The aim of this paper is to evaluate the suitability of the Global Forest Change datasets for national-level MRV reporting, and the objectives are: (a) to assess the percent tree canopy cover threshold (i.e., the density of tree canopy coverage) in the Global Forest Change data that best corresponds to the forest definition for Guyana, and (b) to compare the Global Forest Change dataset forest change estimates against the Guyana-MRV maps for the period between 2001 and 2017.

\section{Materials and Methods}

\subsection{Study Area}

Guyana is a tropical country located on the Caribbean coast of South America and lies between $2^{\circ}$ to $8^{\circ} \mathrm{N}$ and $57^{\circ}$ to $61^{\circ} \mathrm{W}$. The country shares common borders with Venezuela, Brazil and Suriname with a land area of 21.1 million ha and forest area of 18.5 million ha (87\%). The Government of Guyana aims to protect and maintain its forests by attracting investment to foster growth and development that follows a low carbon emissions pathway.

\subsection{Mapping Data}

\subsubsection{University of Maryland (UMD) Global Forest Change Datasets.}

This study uses the Global Forest Change data as described in Hansen et al. [16]. This dataset was downloaded and clipped to Guyana's national boundary and the following layers extracted: Tree canopy cover for year 2000; Global forest cover loss 2000-2017 (Loss); Global forest cover gain 2000-2017 (Gain). 
Tree canopy cover is defined as the density of tree canopy coverage of the land surface. Tree cover loss is defined as stand replacement disturbance, or the complete removal of tree cover canopy at the Landsat pixel scale. Tree cover gain is defined as the establishment of tree canopy at the Landsat pixel scale in an area that previously had no tree cover.

\subsubsection{Guyana-Measurement Reporting and Verification (MRV) System Maps}

In 2009, the Governments of Guyana and Norway agreed to cooperate on emission reduction goals under the umbrella of UNFCCC-REDD+. The activity resulted in a Joint Concept Note to develop an MRV system for a comprehensive, consistent, transparent and verifiable assessment of forest-based greenhouse gas emissions-related indicators (GOFC-GOLD, 2016; GFOI, 2016). Guyana provided in its submission to the UNFCCC its definition of forest land cover used in the construction of its proposed forest reference level for greenhouse gas emissions, which is a minimum area of 1.0 ha, a minimum height of $5 \mathrm{~m}$ and a minimum tree canopy cover of 30 per cent. This definition is based on the Marrakech Accords (Decision 11/CP.7 [39]), and is part of the Guyana Norway Bilateral on Climate and Forests under which there has been payment for REDD+ performance following independent third party verification: https:/forestry.gov.gy/mrvs-interim-measures-reports/, and has been the basis of Guyana's submission of Reference Level to the UNFCCC and the Technical Assessment Report assessment.

Forest area was mapped by the Guyana Forestry Commission by excluding non-forest land cover types, such as water bodies, infrastructure, mining and non-forest vegetation. The first epoch for mapping forest and non-forest land cover was 1990; from that point forward land cover change from forest to non-forest was mapped and labelled with the land cover class and by change driver (e.g., mining, agriculture, logging, and infrastructure). The mapping forms an integral part of the MRV system and uses a rule-based semi-automated processing of national satellite image coverage to identify and record all forest change events, equal to or greater than 1 ha for deforestation and less than 1 ha for forest degradation. Landsat TM and ETM+ imagery covered epochs: 1990, 2000, 2005, 2009 and 2010. RapidEye multispectral imagery covered epochs: 2011, 2012, 2013, and 2014. Sentinel-2 imagery covered epochs: 2015, 2016, and 2017 (see Table 2).

Table 2. Data sets used for mapping and accuracy assessment of Guyana-MRV maps. The reference datasets were also used for the accuracy assessment of the Global Forest Change datasets. As seen, the Guyana-MRV data sets changed through time, as higher resolution datasets became available.

\begin{tabular}{ccc}
\hline \multirow{2}{*}{ Periods } & \multicolumn{2}{c}{ MRV Data Sets } \\
\cline { 2 - 3 } & Mapping Data & Reference Data \\
\hline 1990-2000 & Landsat from 1990 and 2000 & Landsat from 1990 and 2000 \\
\hline $2001-2005$ \& 2006-2010 & Landsat & Landsat \\
\hline $2010-2011$ & Landsat \& DMC & $\begin{array}{c}\text { Landsat, RapidEye, CBERS, } \\
\text { IKONOS, WorldView, \& DMC }\end{array}$ \\
\hline 2011-2012 & RapidEye & $\begin{array}{c}\text { Aerial imagery, WorldView, } \\
\text { QuickBird, \& RapidEye }\end{array}$ \\
\hline 2012-2015 annually & RapidEye & Aerial imagery \& RapidEye \\
\hline 2015-2017 annually & Sentinel-2 & Aerial imagery \& PlanetScope \\
\hline
\end{tabular}

\subsection{Reference Data}

A critical component of any comparative assessment is appropriate reference data [40-43], which allows forest/non-forest land cover to be classified with certainty. In Guyana's case, the wall-to-wall MRV mapping has been verified independently using a probability-based accuracy assessment and interpretation of $0.25 \mathrm{~m}$ digital CIR (Colour InfraRed) vertical aerial imagery and independent analysis of RapidEye imagery. Figure 1 shows a typical example of the image datasets used for this study. 


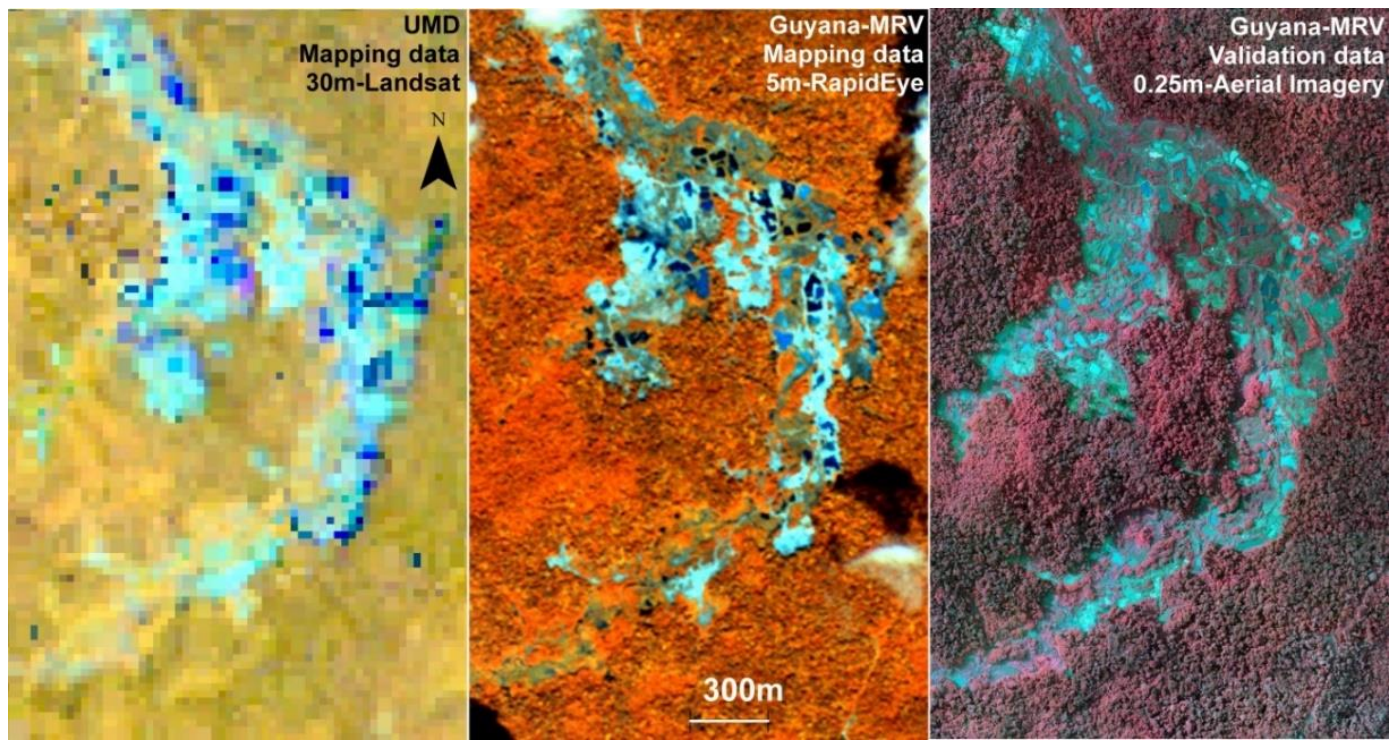

Figure 1. Mapping and validation data sets used to compare the University of Maryland (UMD) (i.e., Global Forest Change) data with the Guyana- measuring, reporting and verification (MRV) maps.

Table 2 provides a list of the reference datasets and includes from the MRV the national mapping datasets and corresponding data used for validation. The combination of the MRV and reference datasets allows for a quantitative comparison of forest loss mapped using two separate wall-to-wall mapping methods.

\subsection{Data Preparation}

In order to compare the Global Forest Change dataset with the Guyana-MRV mapping, there is a need to establish a common reference between the two datasets for the year 2000. This is a necessary pre-processing step [44,45]. Although both the Global Forest Change dataset and Guyana-MRV mapping used Landsat $(30 \mathrm{~m})$ for setting up the reference year 2000, there is a difference in the definition of what is mapped as a "forest" area. The "percent tree cover" in the Global Forest Change dataset is defined as the density of tree canopy coverage of the land surface, which is a modelled metric of spectral information from a continuous field training data that contained a wide range of spectral and spatial mixtures. It is derived from regression tree classification of MODIS and then resampled with Landsat imagery [23]. On the other hand, the Guyana-MRV reference year 2000 forest map was created through assisted manual interpretation, following Guyana accepted definition of forest (see Section 2.2.2. in this paper).

This difference between the two definitions needs to be aligned so as not to propagate any definition difference to the forest change estimates comparison. To achieve this, best correspondence for year 2000 needs to be established first by identifying the density of tree canopy coverage metric that matches the Guyana-MRV map, before proceeding to further comparison of the two datasets. This alignment is not an adjustment of classification rules for forest, or an effort to manipulate the data until the figures fit.

\subsubsection{Preprocessing of the Global Forest Change Tree Canopy Cover Map for the Year 2000}

Each $30 \mathrm{~m}$ by $30 \mathrm{~m}$ pixel in the Global Forest Change product for year 2000 is labelled according to an estimated tree cover percentage [31]. The analysis is based on three key steps: 
1. Prepare tree cover percentage maps for the year 2000 using the online Global Forest Change raster data:

i. Download and review the Global Forest Change tree cover percentage raster datasets for the year 2000.

ii. Produce binary rasters of forest (1) and non-forest (0) area using threshold values of tree cover percentages in increments of 1 (one) starting from 30\% to $100 \%$.

iii. Vectorise the series of binary rasters of forest/non-forest classes.

iv. Calculate the area of forest and non-forest classes for each canopy cover percentage threshold starting from $30 \%$ through to $100 \%$.

2. Generate a non-forest map for year 2000 using data from the Guyana-MRV.

i. The Guyana-MRV 2000 forest/non-forest map was prepared by combining two separate maps: the 1990 forest/non-forest map and the 1990-2000 forest loss map. These two maps were originally prepared using $30 \mathrm{~m}$ Landsat imagery. Subsequently, the forest/non-forest borders were refined using $5 \mathrm{~m}$ RapidEye imagery.

ii. The non-forest map only included areas that were mapped as a loss from a forest to a non-forest state during the period 1990-2000.

3. Finally, the Global Forest Change and Guyana-MRV datasets were compared using the non-forest class from the year 2000 Global Forest Change data for tree canopy cover percent values from 30 to 100 (from step 1) and Guyana-MRV (from step 2).

\subsubsection{Global Forest Change Maps 2001-2017}

For the Global Forest Change dataset, trees are defined as all vegetation taller than $5 \mathrm{~m}$; forest loss is defined as a stand-replacement disturbance meaning that selective logging or thinning that does not lead to a complete loss of canopy cover, so is not included in the change maps; forest gain is defined as the inverse of loss, or a non-forest to forest change and where percent tree crown cover densities exceed $50 \%$ cover [23]. A composite map layer was produced using a GIS by combining all annualised 2001 to 2017 Global Forest Change loss and gain datasets. This map layer was then compared both with the Guyana-MRV maps and independent reference data to assess accuracy.

\subsection{Determining Map Accuracy}

The accuracy of the Global Forest Change dataset and the Guyana-MRV (forest and non-forest) mapping was assessed against independent high resolution reference imagery at randomly sampled locations [46]. The reference datasets (see Table 2) include RapidEye, Worldview, QuickBird, IKONOS, PlanetScope, and digital aerial imagery. In addition, Landsat TM/ETM+ and DMC data were used to establish that observed deforestation events were assigned to the correct year. From 2015 to 2017, Sentinel-2 was used for MRV mapping, while PlanetScope and digital aerial imagery were the reference datasets for accuracy assessment (see Table 2). In earlier years, different combinations of datasets were used.

A statistical assessment of map accuracy used a two-stage stratified sampling design [47] with the first stage being $322(1 \mathrm{~km} \times 3 \mathrm{~km})$ random primary sampling units (PSUs) and within each PSU systematic sampling of 300 one-hectare secondary sampling units (SSUs). Maps of historical deforestation events and infrastructure layers such as settlements, mining, and roads were used for stratification to produce three strata based on potential for land cover change [48].

After establishing the correspondence between Global Forest Change and Guyana-MRV for the year 2000, the Global Forest Change tree cover percentage for that correspondence was converted to a Boolean thematic map where 1 (one) is assigned when equal or more than the corresponding tree cover percentage and 0 (zero) for the remaining pixels. This was then multiplied with the forest gain/loss map to extract the "changes" that occurred at the corresponding tree cover percentage. 
The Global Forest Change datasets are provided in raster format. They were converted to polygon vector without simplification of the output (i.e., any pixelation was retained). Only the deforestation areas (Global Forest Change or Guyana-MRV) within the PSUs were kept for the next step through a clipping/subsetting process. Following that, forest loss area information per SSU was computed for both Global Forest Change and Guyana-MRV datasets. Then, each SSU is compared against Guyana's MRV forest definition, to determine its forest status, i.e., Forest or NonForest (as shown in Figure 2). For example, any forest change events in the Global Forest Change dataset that are one or two Landsat pixels in size would not constitute a forest loss event, and this corresponds with the forest loss definitions used in Guyana-MRV.

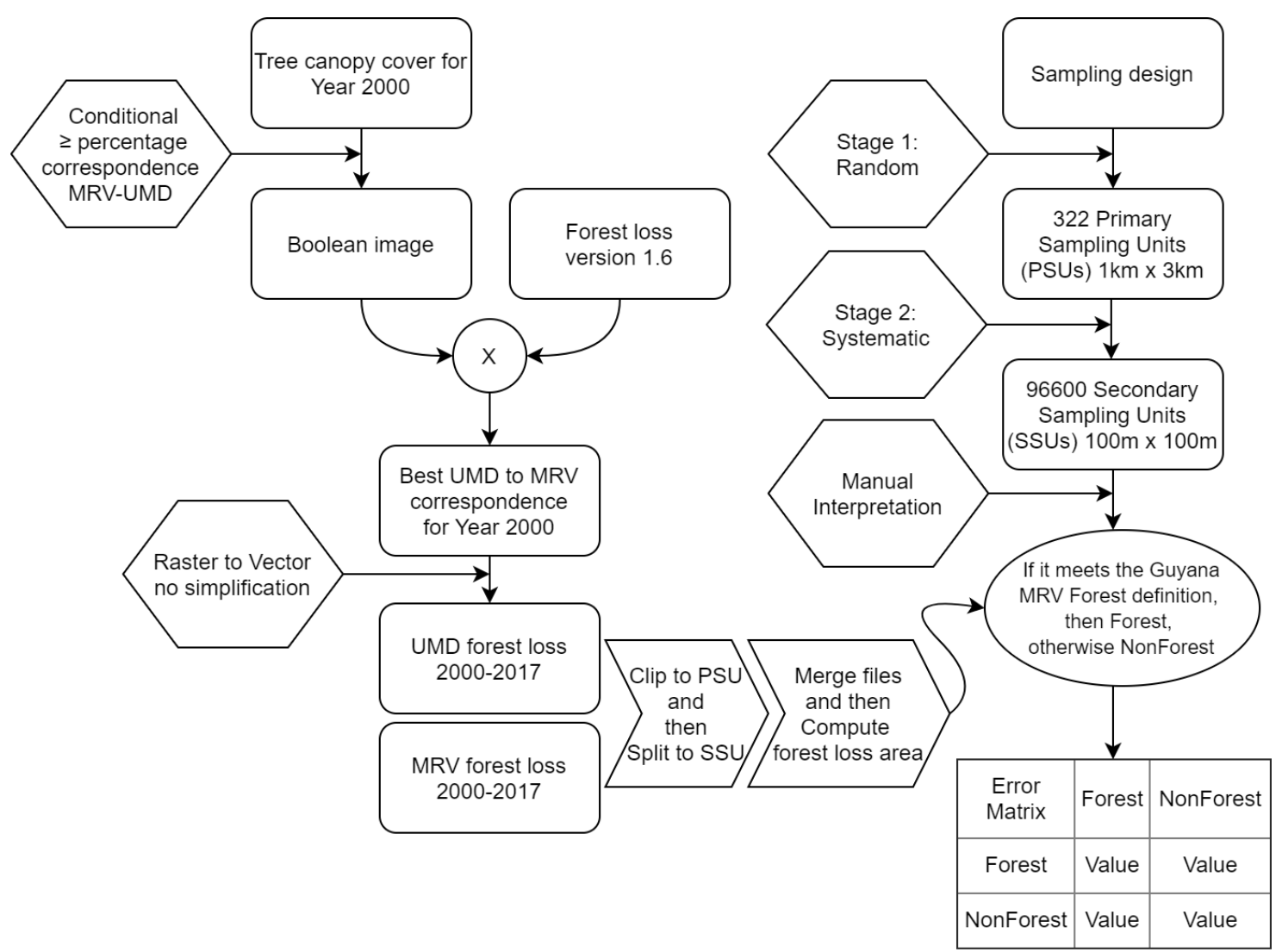

Figure 2. Diagram of the methodology used to compare the Guyana-MRV and the UMD (i.e., Global Forest Change) data sets. Forest loss version 1.6 relates to Global Forest Change forest loss up to and including 2018. The Global Forest Change forest loss is converted to the same format so as to match the MRV forest loss dataset. Then both maps are matched at the secondary sampling unit (SSU) level, and compared against the reference dataset, following the Guyana-MRV forest definition.

\section{Results}

The first objective of the study was to evaluate the ability of the Global Forest Change dataset to produce a straightforward forest/non-forest map. Such a map is a common feature of MRVs as it identifies the area that needs to be monitored for deforestation and forest degradation. The results firstly compare the Global Forest Change and Guyana-MRV forest and non-forest maps generated for the year 2000 (Figures 2 and 3). Then, they qualify the Global Forest Change dataset accuracy at different canopy thresholds through the interpretation of high-resolution imagery over the 322 PSUs (Figure 4). 


\subsection{Comparison of Forest/Non-Forest Area for the Year 2000}

Figure 3 shows at the national-level the difference in the non-forest area between the Global Forest Change and the Guyana-MRV datasets for year 2000. This is plotted to illustrate the change in the non-forest area when different tree canopy cover threshold values are selected from the Global Forest Change product. Using the 30\% tree canopy threshold underestimates Guyana's non-forest area (or overestimates forest area) by 483,000 ha $(18.15 \%$ ). The closest match between the Guyana-MRV non-forest area and the Global Forest Change canopy cover is achieved using a $94 \%$ tree canopy cover threshold with a difference of only 24,210 ha $(0.91 \%)$ between the two maps.

For illustration, the same information is presented in map form where for the country in year 2000 the forest area is shown in green and the non-forest area is shown in black (Figure 4). The upper two map panels show the Guyana-MRV forest/non-forest map and for reference the RapidEye $5 \mathrm{~m}$ false colour composite image. The lower three panels show the Global Forest Change forest/non-forest maps at tree canopy cover thresholds of 30\%,94\%, and 95\%. Across the area of interest, the Global Forest Change dataset underestimates the non-forest area at the 30\% threshold, it matches well at $94 \%$ threshold, and overestimates at $95 \%$ or above.

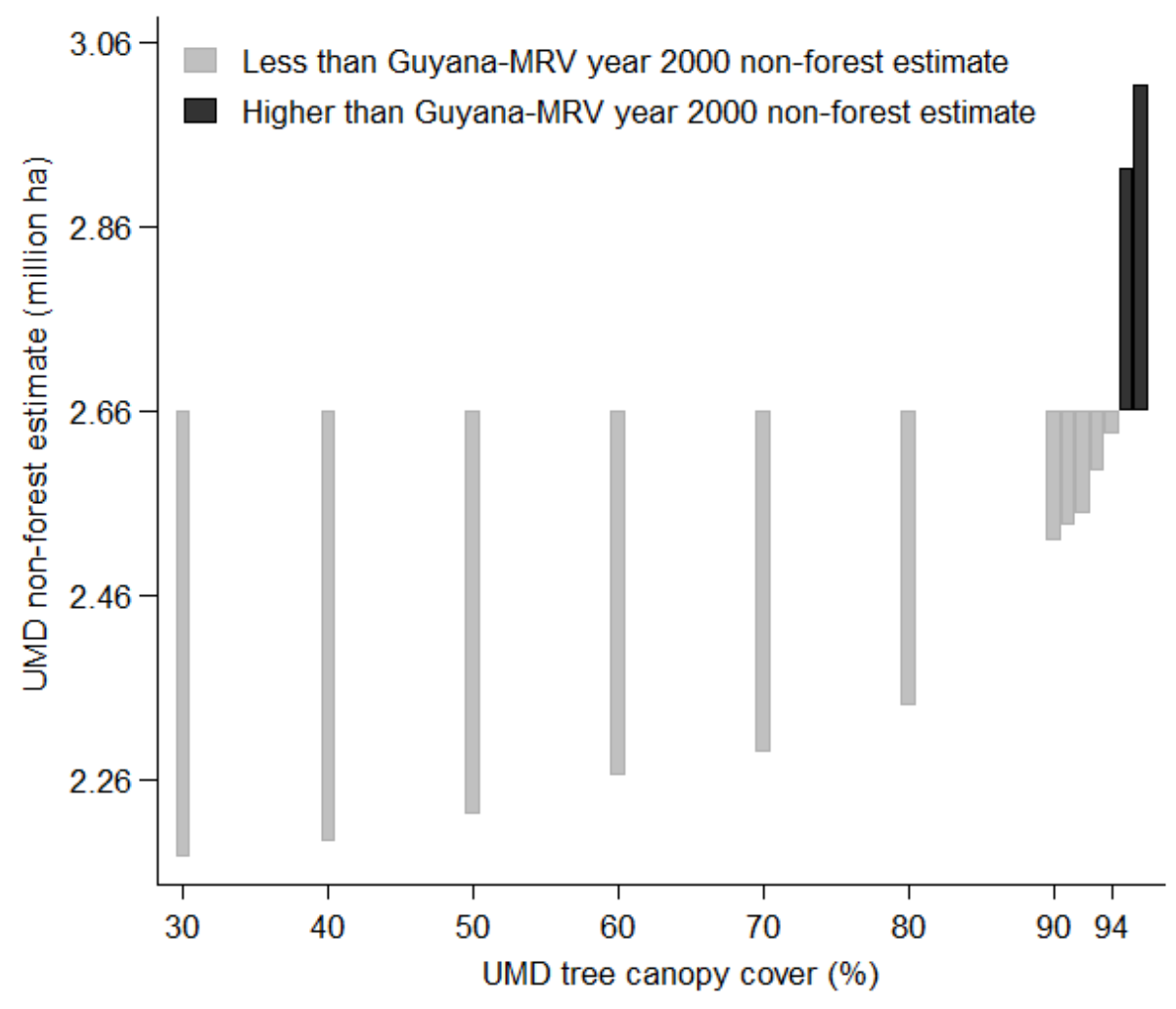

Figure 3. The non-forest area of Guyana from the Global Forest Change year 2000 Percent Tree Cover product at different tree canopy cover percentage values (30\%-96\%) plotted against the proportion of non-forest area mapped in the year 2000 Guyana-MRV. 

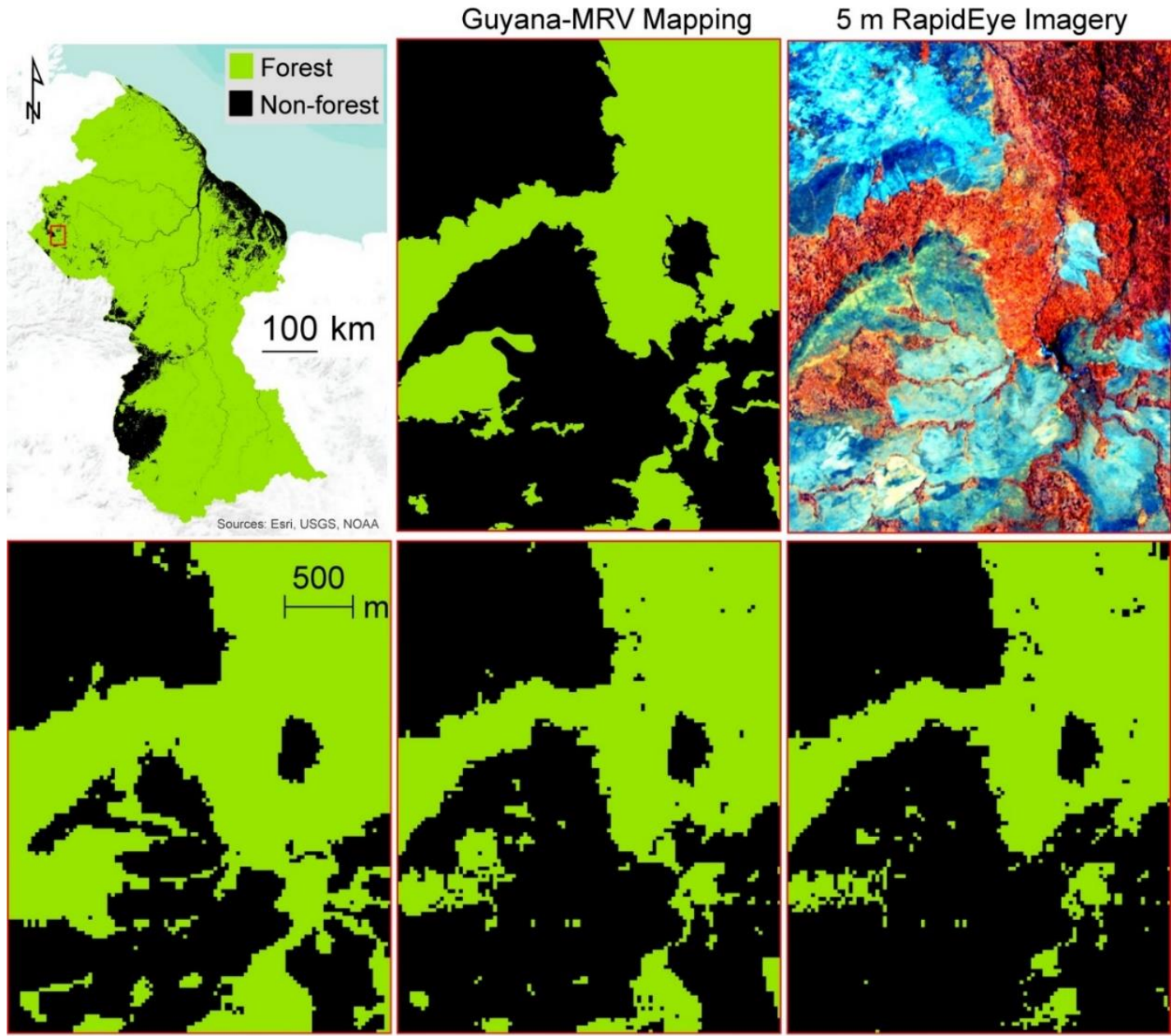

UMD Mapping (0-30\%)

UMD Mapping (0-94\%)

UMD Mapping (0-95\%)

Figure 4. Guyana non-forest in year 2000: Global Forest Change tree canopy cover values (\%) at 30, 94, and 95, Guyana-MRV and RapidEye imagery (reference data).

\subsection{Accuracy Assessment of the Year 2000 Global Forest Change Non-Forest Map}

Within each of the PSUs, the proportion of non-forest area of the Guyana-MRV layer was calculated and compared to the Global Forest Change data using the 30\% and $94 \%$ tree canopy cover thresholds. The results shown in Figure 5 echo the national-level analysis and demonstrate that for the Global Forest Change product the $94 \%$ canopy threshold $\left(R^{2}=0.98\right)$ yields the closest correspondence. By comparison, the $30 \%$ canopy threshold data shows the greatest scatter $\left(R^{2}=0.91\right)$, indicating that the best match between the Guyana-MRV forest/non-forest map and the Global Forest Change forest/non-forest map occurs when a $94 \%$ tree canopy cover threshold is used.

\subsection{Accuracy of Forest Loss Maps 2001-2017}

The second aspect of the study compares the accuracy of the 2001 to 2017 Global Forest Change map (loss/gain) against the Guyana-MRV maps for the same period. From a practical perspective, a close correspondence between these two values gives confidence that the Global Forest Change datasets can assist in providing national-level forest change estimates. An accepted approach for presenting quantitative measure of map accuracy is an error matrix, so-called as it considers commission and omission errors relative to an accurate reference dataset.

Using this approach, the accuracy of the Global Forest Change forest loss map for the period 2001 to 2017 is presented in Table 3. 


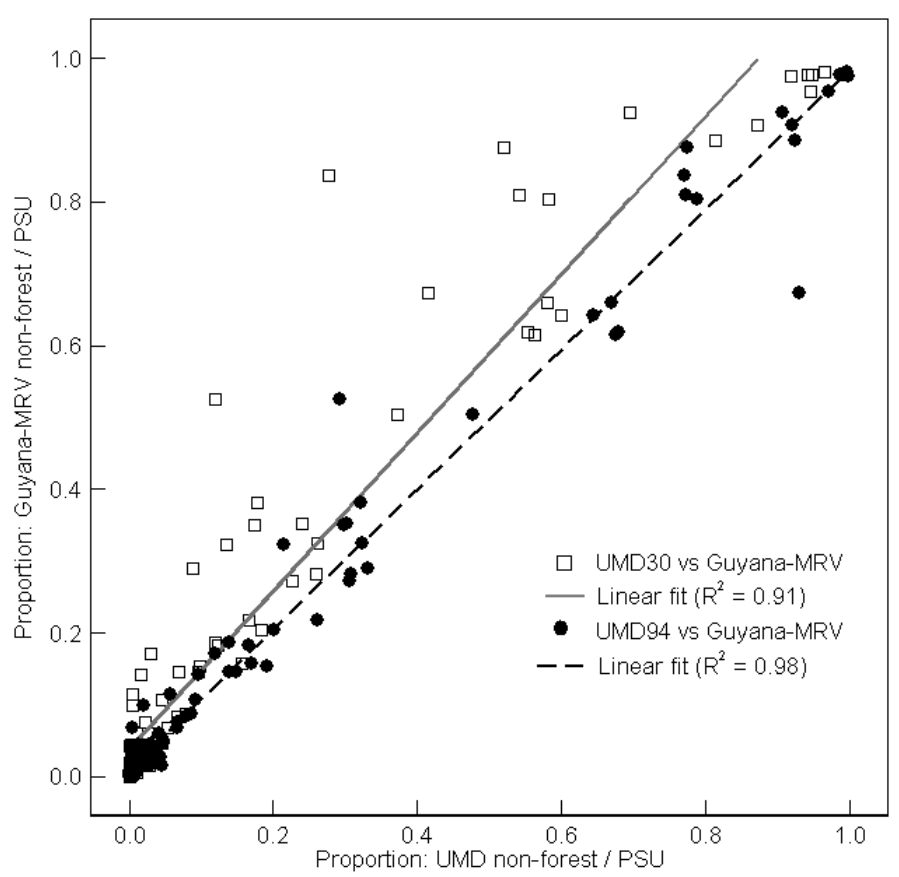

Figure 5. Proportion of non-forest cover in the year 2000 UMD (i.e., Global Forest Change) \% Tree Cover map for the 322 primary sampling units plotted against the respective non-forest area in the Guyana-MRV. The plot compares UMD tree canopy cover values at $30 \%$ and $94 \%$.

Table 3. Error matrix showing the cumulative correspondence between the Global Forest Change and Guyana-MRV forest loss maps and the reference data between 2001 and 2017. The units for all data are in hectares.

\begin{tabular}{|c|c|c|c|c|c|}
\hline \multicolumn{6}{|c|}{ Overall Error Matrix for Global Forest Change } \\
\hline \multirow{4}{*}{$\begin{array}{c}\text { Global Forest } \\
\text { Change }\end{array}$} & & \multicolumn{2}{|c|}{ Reference data } & \multirow{2}{*}{ Total } & \multirow{2}{*}{$\begin{array}{c}\text { Users } \\
\text { accuracy }\end{array}$} \\
\hline & & Forest & Non-forest & & \\
\hline & Forest & 86,777 & 522 & 87,299 & $99.40 \%$ \\
\hline & Non-forest & 114 & 8714 & 8828 & $98.71 \%$ \\
\hline \multicolumn{2}{|c|}{ Total } & 86,891 & 9236 & 96,127 & \\
\hline \multicolumn{2}{|c|}{ Producer accuracy } & $99.87 \%$ & $94.35 \%$ & & $99.34 \%$ \\
\hline \multicolumn{6}{|c|}{ Overall error matrix for Guyana-MRV } \\
\hline \multirow{4}{*}{ Guyana-MRV } & & \multicolumn{2}{|c|}{ Reference data } & \multirow{2}{*}{ Total } & \multirow{2}{*}{$\begin{array}{c}\text { User } \\
\text { accuracy }\end{array}$} \\
\hline & & Forest & Non-forest & & \\
\hline & Forest & 86,651 & 375 & 87,026 & $99.57 \%$ \\
\hline & Non-forest & 240 & 8861 & 9101 & $97.36 \%$ \\
\hline \multicolumn{2}{|c|}{ Total } & 86,891 & 9236 & 96,127 & \\
\hline \multicolumn{2}{|c|}{ Producer accuracy } & $99.72 \%$ & $95.94 \%$ & & $99.36 \%$ \\
\hline
\end{tabular}

Table 3 shows the correspondence between the Guyana-MRV and the independent reference data. For all strata, the overall correspondence is $99.00 \%$ or better. While the overall accuracy of both map products looks promising at $99.34 \%$ (Global Forest Change) and $99.36 \%$ (Guyana-MRV), it is the distribution of errors that requires consideration when estimating areas and rates of forest loss. The key difference is that the non-forest area is well mapped in the Guyana-MRV (95.94\%) whereas the non-forest area is less well mapped in the Global Forest Change dataset (94.35\%).

Table 4 illustrates that the main difference between the Global Forest Change and Guyana-MRV forest loss datasets occurs in the non-forest class, meaning areas that experience deforestation (as seen 
in the reference data) are more likely to be detected and mapped as loss in the Guyana-MRV than the Global Forest Change dataset.

Table 4. Error matrix showing the cumulative correspondence between the Global Forest Change and Guyana-MRV forest loss datasets from 2001 to 2017. The units for all data are in hectares.

\begin{tabular}{cccccc}
\hline \multirow{3}{*}{\begin{tabular}{c} 
Global Forest $\begin{array}{c}c \\
\text { Change }\end{array}$ \\
\cline { 2 - 4 }
\end{tabular}} & & Forest & Non-Forest & Total & Users Accuracy \\
\cline { 2 - 5 } & Forest & $\mathbf{8 6 , 9 1 8}$ & $\mathbf{4 0 4}$ & $\mathbf{8 7 , 3 2 2}$ & $\mathbf{9 9 . 5 4 \%}$ \\
\cline { 2 - 5 } & Non-Forest & $\mathbf{3 4 9}$ & $\mathbf{8 5 4 6}$ & $\mathbf{8 8 9 5}$ & $\mathbf{9 6 . 0 8 \%}$ \\
\hline \multicolumn{2}{c}{ Total } & 87,267 & 8950 & 96,217 & \\
\hline \multicolumn{2}{c}{ Producer accuracy } & $99.60 \%$ & $95.49 \%$ & & $99.22 \%$ \\
\hline
\end{tabular}

Figure 6 illustrates the spatial distribution of forest loss across Guyana from 2001 to 2017 of the Global Forest Change and Guyana-MRV datasets, respectively. The datasets highlight two patterns; first, the Global Forest Change dataset shows forest loss as widely distributed across the whole country, while the Guyana-MRV dataset shows the loss as concentrated pockets of change, often associated with a single time period. Secondly, the Global Forest Change dataset shows many small areas of change in the central and the southern parts of Guyana (the expanded box) in areas where there is no road access or possibility of logging or mining activity due to inaccessibility and mountainous topography. It is possible that natural processes that cause forest change such as floods, erosion, fire or storm events may have occurred. However, it is very unlikely that these changes would be widely dispersed over the largely undisturbed forests of southern Guyana. As seen in Figure 6, the Guyana-MRV data for the same area shows large areas of undisturbed forest and a smaller number of change sites concentrated around the forest-savannah margin and a few other discrete areas with known road access.

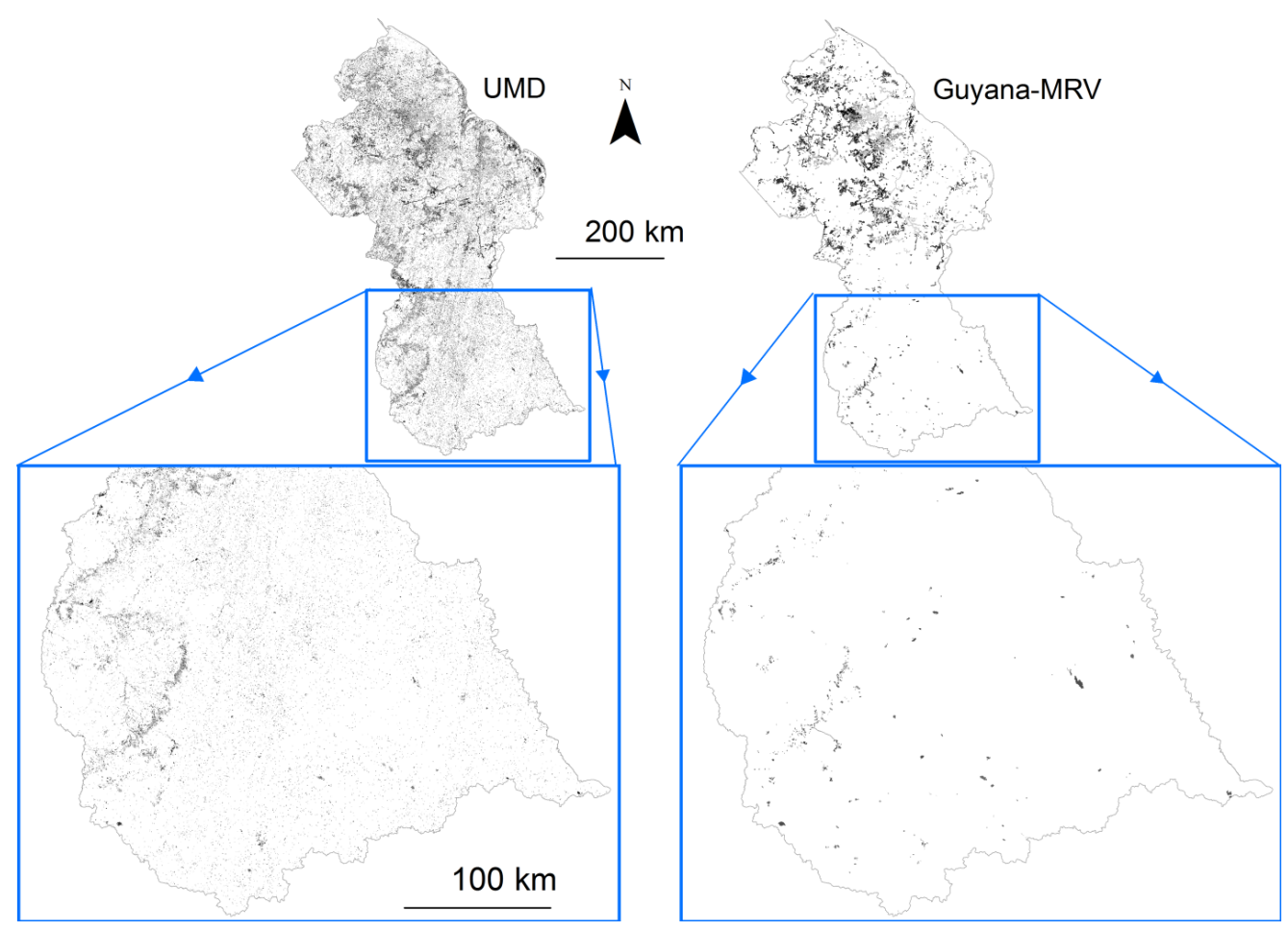

Figure 6. Spatial distribution of cumulative forest loss events in Guyana between 2001 and 2017 as mapped by the Global Forest Change (left) and Guyana-MRV (right). More recent events are presented in black and older events are presented in fading grey colours. 


\subsection{Forest Loss Estimates: 2001-2017}

Forest loss was calculated from the Global Forest Change annualized forest loss map by aggregating change from 2001 through to 2017. For comparison, the Guyana-MRV generated wall-to-wall forest loss maps covering the same time periods: 2001-2005, 2006-2009, 2010, 2011, 2012, 2013, 2014, 2015-2016, and 2017. (Table 2).

Figure 7 compares forest loss in hectares for the corresponding time periods. From 2001 to 2010, both the Global Forest Change and Guyana-MRV used Landsat data to estimate forest loss. From 2011, the Guyana-MRV began mapping forest loss using RapidEye data, starting first in the north of Guyana, and by 2012 covering the entire country. From 2015, the Guyana-MRV switched to Sentinel-2 data with support from Landsat.

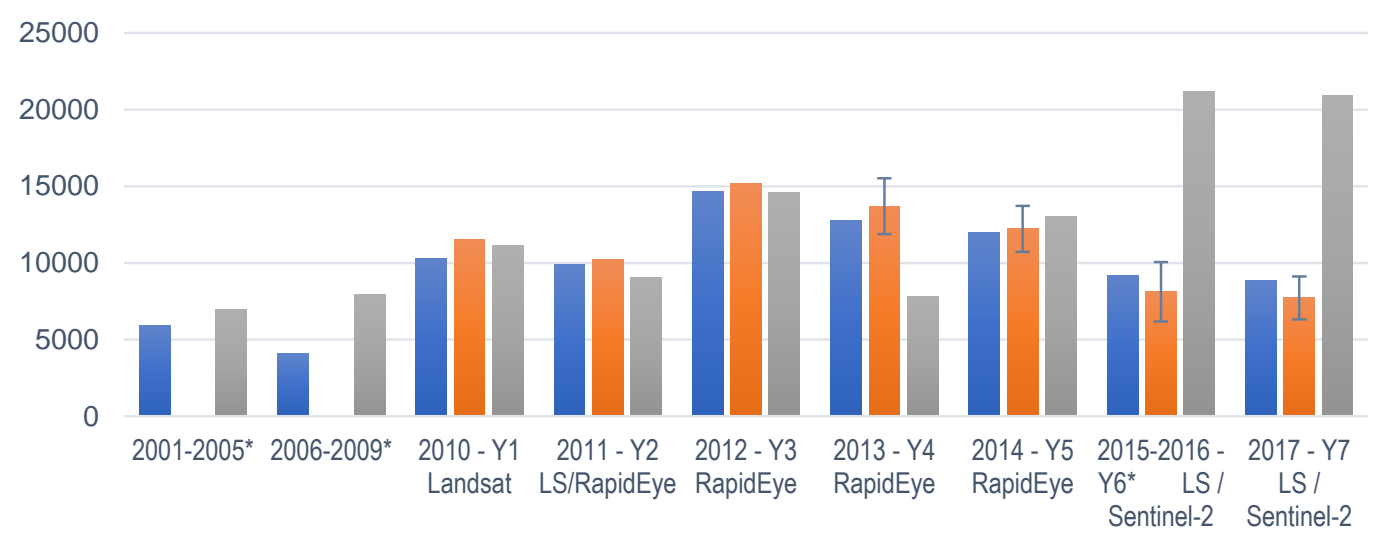

-Deforestation Area from National Map —Deforestation Area from sample-based estimation «UMD (94\%)

Figure 7. Annual forest loss estimates between 2001 and 2017 in Guyana estimated from UMD (i.e., Global Forest Change) maps, Guyana-MRV maps and sample-based estimation. The Y-axis denotes forest loss in hectares (ha). * annual average.

The trends shown in Figure 7 indicate that in the period up to 2013, the Global Forest Change estimated a similar level of forest loss to the Guyana-MRV mapping. In 2013, the Global Forest Change dataset shows less forest loss than the MRV maps. The year 2014 showed similar levels of forest loss and 2015-2016 and 2017 show much greater levels of forest loss than the Guyana-MRV mapping and sample-based estimates. Interestingly, for the year 2010, the two forest loss estimates were almost identical; both were derived from Landsat data but using independent mapping methods. From 2011 to 2014, as the Guyana-MRV incorporated higher resolution RapidEye imagery, the forest loss estimates start to diverge, with 2013 standing out. From 2015 to 2017, the Guyana-MRV incorporated Sentinel-2 with support from Landsat, but while one might expect a trend similar to the pre-RapidEye period, the Global Forest Change estimate of forest loss is more than double the MRV and sample-based estimates.

From 2013-2017, an independent probability-based change sample analysis estimates forest loss at a very similar level to the wall-to-wall mapping of the Guyana-MRV data. The Global Forest Change estimate falls outside the 95\% confidence interval of the probability-based estimate for 2013, 2015-2016 and 2017 (see Figure 7).

\subsection{Quality of Annualized Forest Change Mapping: 2001-2017}

In Guyana, the Global Forest Change datasets provide a product that helps to indicate the general location of change for any given year. By way of example, Figure 8 shows an area of alluvial gold mining in northern Guyana where forest loss was mapped as a near-continuous process from 2001 
through to 2014. This time-series example shows that, for any one year, the Global Forest Change dataset detects change but misses fine detail around the forest/non-forest boundary.

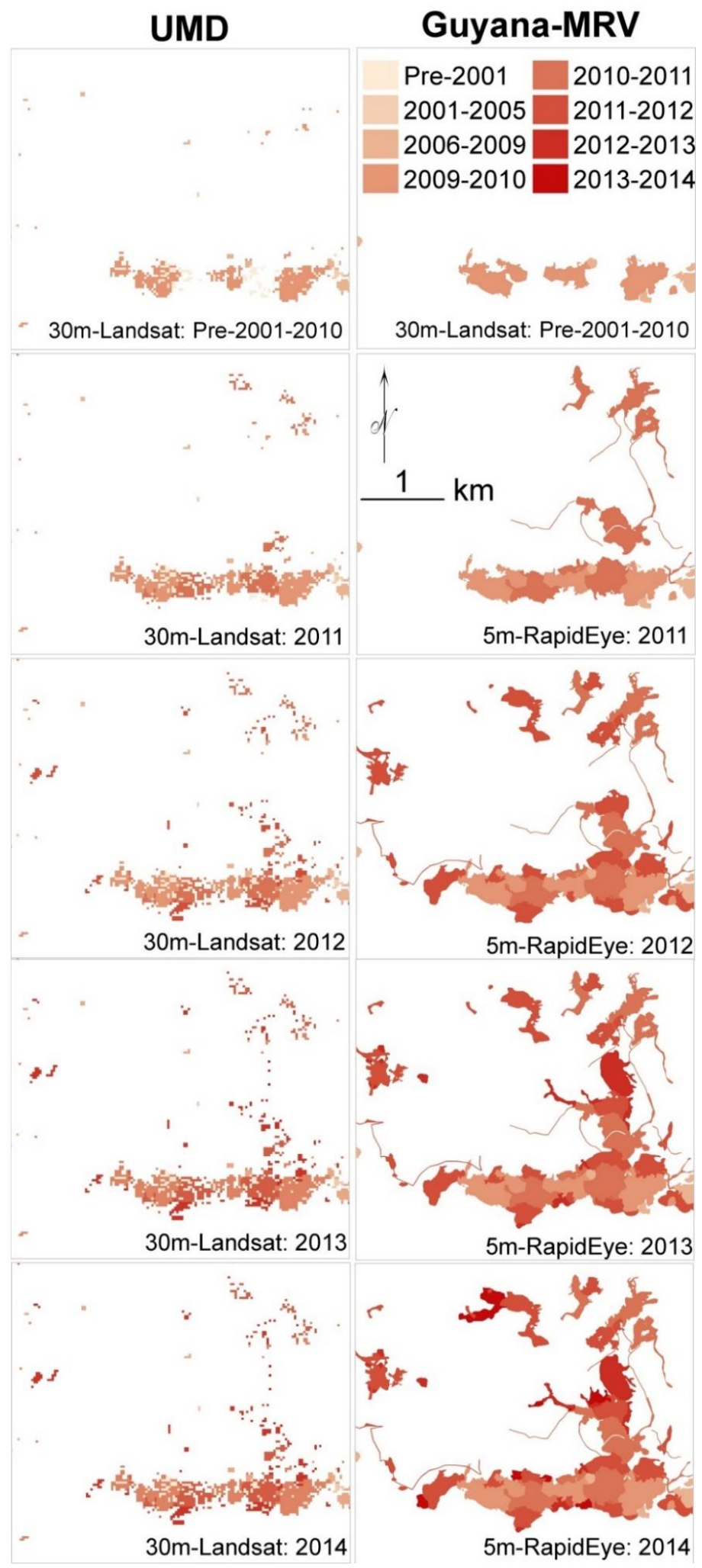

Figure 8. Maps of change in an alluvial gold mining area in Guyana where forest loss has been mapped in the UMD (i.e., Global Forest Change) (left) and Guyana-MRV maps (right) between pre-2001 and 2014 for illustration only. 


\section{Discussion}

For the first objective of the study, analysis showed that a 94\% canopy cover threshold in the Global Forest Change data corresponds most closely with the Guyana-MRV year 2000 forest/non-forest map. There are two possible explanations for the difference between the datasets. First, the Global Forest Change year 2000 tree canopy cover percentage map was derived from the $250 \mathrm{~m}$ MODIS Vegetation Continuous Fields (VCF), then rescaled down to $30 \mathrm{~m}$ resolution [31]. This rescaling process limits the ability of the dataset to capture tree canopy cover values on the ground at $30 \mathrm{~m} \times 30 \mathrm{~m}$ as it is derived from a coarser resolution product. Secondly, high-resolution reference data show that a substantial portion of the forest in Guyana maintains a uniform canopy cover, much higher than the $30 \%$ value. While only forests along the edges of the forest/non-forest boundary exhibit variable canopy cover values, this is where most of the inconsistency is found between the Global Forest Change datasets and the Guyana-MRV forest/non-forest map.

GFOI [12] and GOFC-GOLD [13] advocate the need for harmonization and standardization in forest definitions in order to make a comparable estimate across different global and national-scale forest cover mapping efforts [49]. This study demonstrates that care needs to be exercised when selecting an appropriate tree canopy cover threshold otherwise for Guyana a systematic overestimation of forest area results. It is interesting to note that a similar bias was reported in a study of forest cover estimation for Gabon in central Africa [39], where the Global Forest Change dataset was compared to national wall-to-wall mapping. Sannier et al. used two tree canopy cover percentage thresholds and showed that the $70 \%$ threshold corresponded best with the reference map and concluded that the mapping errors in the Global Forest Change data were non-negligible and so the resultant maps could not be used to generate national forest cover statistics for Gabon without appropriate sample reference data [39].

Hansen et al. [31] reported User's and Producer's accuracies of 80\% or better for the Global Forest Change datasets in the tropical biome and for the globe as a whole. In comparison, the results in this second part of the study for Guyana, based on independent reference data, yield an overall accuracy of $99.34 \%$ with Producer's and User's accuracies of $94.35 \%$ to $98.71 \%$ respectively. The agreement is an aggregate value for change over the period 2001-2017; for any individual year the agreement will be less, mainly due to the lack of availability of cloud-free imagery at the start or end of the annual census period and because Global Forest Change detects all change whether it meets the strict definition of deforestation or not. The Global Forest Change and Guyana-MRV data show an overall agreement of $97.50 \%$ but within that figure it is difficult to be certain about the level of agreement in any given year. The differences between the Global Forest Change and Guyana-MRV forest loss estimates are most likely due to the ambiguity in defining the forest/non-forest boundaries because of the $30 \mathrm{~m}$ Landsat pixel, the differing scales of measurements [50], and the automatic classification algorithm used to detect change. On the other hand, the Guyana-MRV dataset is better aligned to the edges of forest change boundaries due to the inclusion of RapidEye data [51].

Broich et al. [52] demonstrated the utility of using a coarser resolution dataset to stratify forest area change by conducting a comparison of sampling designs between systematic, simple random, and stratified random for the Brazilian Legal Amazon between 2000 and 2005. The study used MODIS-derived deforestation data at a $500 \mathrm{~m}$ spatial resolution to stratify the observed forest change when assessed against the $120 \mathrm{~m}$ derived product. In the case of Guyana, Pickering et al. demonstrate the utility of Landsat-based forest loss maps to provide strata to improve precision of area estimators produced from a samples of imagery in countries like Guyana where forest loss and degradation are relatively rare [53].

Detailed comparison of the Global Forest Change dataset reveals some errors, mainly associated with the $30 \mathrm{~m}$ pixel size and the time of image acquisition relative to each census year. The latter impacts on the ability of the maps to allocate change precisely to any given year/census period from 2001 through to 2017. A strength of the Global Forest Change dataset is that it provides a spatial map 
of loss and gain, even if the change may be due to natural processes it is valuable to be able to visualise change on an annual basis.

The area estimation and accuracy assessment (estimation of uncertainty in area estimates) follows international best practice guidelines [15,16,42,54-57]. In assessing the quality of binary maps of forest/non-forest landscapes, the classification accuracy can be misleading in the case of both User and Producer accuracy and omission and commission errors or bias as shown by [39,58]. The MODIS VCF product contains the amount of tree canopy cover for any pixel over the terrestrial surface of Earth scaled from 0 (no canopy coverage) to 100 (complete canopy coverage) [31]. In addition, the Landsat-based Global Land Cover Facility (GLCF) tree cover 2000 dataset, rescaled from MODIS VCF, showed poor performance in the humid tropics [37]. The results identify an overestimation of forest cover in the Global Forest Change dataset in the year 2000 tree canopy cover percent, even though errors in forest loss tend to be averaged out over the period 2001-2017.

Persistent cloud cover is a particular problem along the Caribbean coastline of South America, and the resultant data gaps may have been a factor that limited the ability of the Global Forest Change datasets to detect precise annual forest change estimates. Other studies report a significant interaction between climatic domain and year [35] which leads to uncertainty in mapping forested areas in tropical regions [38]. The influence of seasonality and the fact that the global change algorithm is applied across the full range of ecological and physical conditions encountered at the global-scale might compromise the reliability of the mapping results [22,25,59]. Given that the Global Forest Change dataset uses a single methodology to derive a pan-global forest change product, it is not surprising to find local differences. Nevertheless, it is important to highlight these differences, and for the scientific community and potential users of change maps to be aware of these and not to use global datasets inappropriately.

With careful interpretation, Landsat can be used for the Guyana-MRV system if the requirement is only to map deforestation events greater than $1 \mathrm{ha}$. The decision to investigate and commission a higher resolution option was necessary due to the requirement for quantifying forest degradation activities and assigning a driver to the change event. The automated nature of the Global Forest Change mapping means that no driver can be assigned to forest change events, but the requirements of REDD+ reporting require the quantification of the difference between anthropogenic forest loss and the loss from natural processes. Essentially, specific reporting on emissions vary by driver, and capturing the spatial extent of each driver is necessary for emissions reporting under REDD+. In recent years, the greatest amount of forest loss in Guyana and several other countries in South America such as Brazil [60] and Peru [61] has been associated with alluvial gold mining and the associated infrastructure which typically follows a narrow ribbon-like patterns following the thalweg of a river course, see Figure 9. In this regard, the pixel size of Landsat is often too large to capture small area change such as ribbon-mining morphology and infrastructure. 


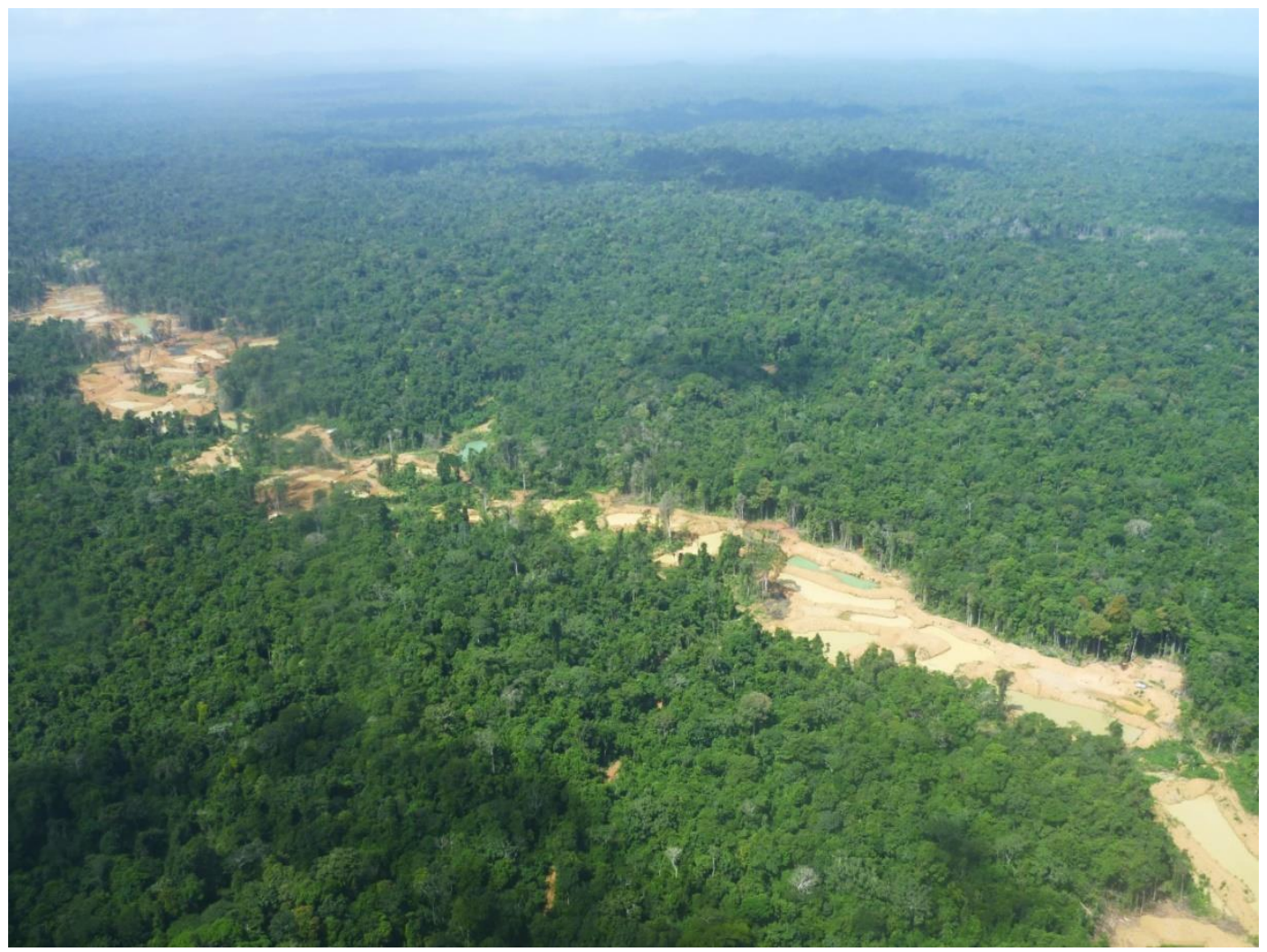

Figure 9. Example of a typical ribbon pattern of alluvial mining practice, which is the major driver of deforestation and forest degradation in Guyana.

\section{Conclusions}

While a relatively small country, this study of Guyana provides an important reference point, as one of the few countries that have developed long-term national-scale wall-to-wall maps of forest cover change. The Government of Guyana, through its cooperation agreement with Norway on emission reduction goals under the umbrella of UNFCCC-REDD+, was one of the first countries to make the move to results-based payments. The study allows us to draw important conclusions likely to be of interest in the context of tropical countries with low rates of deforestation.

Global Forest Change datasets have great potential to assist developing countries like Guyana with national forest cover monitoring, reporting and change verification requirements. Given the limitations of the FRA in providing consistent data at a national level [62], the Global Forest Change mapping follows a consistent methodology and provides long-term (loss and gain) trend data [10]. Nevertheless, users should be aware of the limitations described in this paper, and that sample-based error-adjustment techniques provide an alternative to approach from which to derive national-scale estimation of gross forest loss from the Global Forest Change datasets [50]. Overall, the following points should be considered when using the global product: (1) it must be understood in relation to local definitions of forest cover; (2) it may under- or overestimate forest loss (or gain); (3) and may have limited applicability in identification of the drivers of forest cover change, which would provide the ability to attribute land use to a land cover change event. These points emphasise the need for high quality reference data, such as those used by Guyana in order to meet UNFCCC reporting and REDD+ audit standards for performance-based payment.

The conclusion is that, when suitably calibrated for percent tree cover, the Global Forest Change datasets give a good first approximation of forest loss (and, probably, gains). However, in countries with large areas of forest cover and low levels of deforestation, these data should not be relied upon 
to provide a precise annual loss/gain or rate of change estimates for audit purposes without using independent reference data.

Author Contributions: Conceptualization, D.N.M.D., P.W. and M.C.H.; Data curation, N.G.; Formal analysis, N.G. and D.N.M.D.; Investigation, N.G., D.N.M.D. and P.W.; Methodology, N.G.; Project administration, P.B.; Resources, P.B.; Software, N.G. and A.R.J.M.; Supervision, D.N.M.D.; Validation, N.G. and D.N.M.D.; Visualization, N.G., J.P. and A.R.J.M.; Writing—original draft, N.G., D.N.M.D. and A.R.J.M.; Writing—review \& editing, N.G., D.N.M.D., P.W. and J.P. All authors have read and agreed to the published version of the manuscript.

Funding: This research received no external funding.

Acknowledgments: Guyana Forestry Commission mapping team.

Conflicts of Interest: The authors declare no conflict of interest.

\section{References}

1. Van der Werf, G.R.; Morton, D.C.; DeFries, R.S.; Olivier, J.G.J.; Kasibhatla, P.S.; Jackson, R.B.; Collatz, G.J.; Randerson, J.T. $\mathrm{CO}_{2}$ emissions from forest loss. Nat. Geosci. 2009, 2, 737. [CrossRef]

2. Achard, F.; Beuchle, R.; Mayaux, P.; Stibig, H.-J.; Bodart, C.; Brink, A.; Carboni, S.; Desclée, B.; Donnay, F.; Eva, H.D.; et al. Determination of tropical deforestation rates and related carbon losses from 1990 to 2010. Glob. Chang. Biol. 2014, 20, 2540-2554. [CrossRef] [PubMed]

3. Tyukavina, A.; Baccini, A.; Hansen, M.C.; Potapov, P.V.; Stehman, S.V.; Houghton, R.A.; Krylov, A.M.; Turubanova, S.; Goetz, S.J. Aboveground carbon loss in natural and managed tropical forests from 2000 to 2012. Environ. Res. Lett. 2015, 10, 074002. [CrossRef]

4. Federici, S.; Tubiello, F.N.; Salvatore, M.; Jacobs, H.; Schmidhuber, J. New estimates of $\mathrm{CO}_{2}$ forest emissions and removals: 1990-2015. For. Ecol. Manag. 2015, 352, 89-98. [CrossRef]

5. Le Quéré, C.; Moriarty, R.; Andrew, R.M.; Peters, G.P.; Ciais, P.; Friedlingstein, P.; Jones, S.D.; Sitch, S.; Tans, P.; Arneth, A.; et al. Global carbon budget 2014. Earth Syst. Sci. Data 2015, 7, 47-85. [CrossRef]

6. UNFCCC. Addendum. Part Two: Action taken by the Conference of the Parties at its fifteenth session. In Proceedings of the Report of the Conference of the Parties on Its Fifteenth Session, Copenhagen, Denmark, 7-19 December 2009; p. 43.

7. UNFCCC. Addendum. Part Two: Action taken by the Conference of the Parties at its sixteenth session. In Proceedings of the Conference of the Parties (COP) Report of the Conference of the Parties on Its Sixteenth Session, Cancun, Mexico, 29 November-10 December 2010; p. 31.

8. UNFCCC. Addendum. Part two: Action taken by the Conference of the Parties at its seventeenth session. In Proceedings of the Conference of the Parties (COP) Report of the Conference of the Parties on Its Seventeenth Session, Durban, South Africa, 28 November-11 December 2011; p. 63.

9. UNFCCC. Addendum. Part two: Action taken by the Conference of the Parties at its twenty-first session. In Proceedings of the Report of the Conference of the Parties on Its Twenty-First Session, Paris, France, 30 November-13 December 2015; p. 36.

10. Grainger, A. Difficulties in tracking the long-term global trend in tropical forest area. Proc. Natl. Acad. Sci. USA 2008, 105, 818-823. [CrossRef]

11. Ramankutty, N.; Gibbs, H.K.; Achard, F.; Defries, R.; Foley, J.A.; Houghton, R.A. Challenges to estimating carbon emissions from tropical deforestation. Glob. Chang. Biol. 2007, 13, 51-66. [CrossRef]

12. Hosonuma, N.; Herold, M.; Sy, V.D.; Fries, R.S.D.; Brockhaus, M.; Verchot, L.; Angelsen, A.; Romijn, E. An assessment of deforestation and forest degradation drivers in developing countries. Environ. Res. Lett. 2012, 7, 044009. [CrossRef]

13. Baccini, A.; Goetz, S.J.; Walker, W.S.; Laporte, N.T.; Sun, M.; Sulla-Menashe, D.; Hackler, J.; Beck, P.S.A.; Dubayah, R.; Friedl, M.A.; et al. Estimated carbon dioxide emissions from tropical deforestation improved by carbon-density maps. Nat. Clim. Chang. 2012, 2, 182. [CrossRef]

14. Keenan, R.J.; Reams, G.A.; Achard, F.; de Freitas, J.V.; Grainger, A.; Lindquist, E. Dynamics of global forest area: Results from the FAO Global Forest Resources Assessment 2015. For. Ecol. Manag. 2015, 352, 9-20. [CrossRef] 
15. GFOI Integration of Remote-Sensing and Ground-Based Observations for Estimation of Emissions and Removals of Greenhouse Gases in Forests: Methods and Guidance from the Global Forest Observations Initiative; 2.0; Food and Agriculture Organization: Rome, Italy, 2016.

16. GOFC-GOLD. A Source Book of Methods and Procedures for Monitoring and Reporting Anthropogenic Greenhouse Gas Emissions and Removals Associated with Deforestation, Gains and Losses of Carbon Stocks in Forests Remaining Forests, and Forestation; GOFC-GOLD Report Version COP22-1; GOFC-GOLD Land Cover Project Office; Wageningen University: Wageningen, The Netherlands, 2016.

17. Lieth, H.; Van der Maarel, E. Classifying and mapping the world's vegetation. Vegetatio 1976, 32, 73-74. [CrossRef]

18. Matthews, E. Global Vegetation and Land Use: New High-Resolution Data Bases for Climate Studies. J. Clim. Appl. Meteorol. 1983, 22, 474-487. [CrossRef]

19. Wilson, M.F.; Henderson-Sellers, A. A global archive of land cover and soils data for use in general circulation climate models. J. Climatol. 1985, 5, 119-143. [CrossRef]

20. DeFries, R.S.; Field, C.B.; Fung, I.; Justice, C.O.; Los, S.; Matson, P.A.; Matthews, E.; Mooney, H.A.; Potter, C.S.; Prentice, K.; et al. Mapping the land surface for global atmosphere-biosphere models: Toward continuous distributions of vegetation's functional properties. J. Geophys. Res. Atmos. 1995, 100, 20867-20882. [CrossRef]

21. DeFries, R.S.; Townshend, J.R.G. NDVI-derived land cover classifications at a global scale. Int. J. Remote Sens. 1994, 15, 3567-3586. [CrossRef]

22. Hansen, M.C.; Defries, R.S.; Townshend, J.R.G.; Sohlberg, R. Global land cover classification at 1 km spatial resolution using a classification tree approach. Int. J. Remote Sens. 2000, 21, 1331-1364. [CrossRef]

23. Hansen, M.C.; DeFries, R.S.; Townshend, J.R.G.; Carroll, M.; Dimiceli, C.; Sohlberg, R.A. Global Percent Tree Cover at a Spatial Resolution of 500 Meters: First Results of the MODIS Vegetation Continuous Fields Algorithm. Earth Interact. 2003, 7, 1-15. [CrossRef]

24. Loveland, T.R.; Belward, A.S. The IGBP-DIS global $1 \mathrm{~km}$ land cover data set, DISCover: First results. Int. J. Remote Sens. 1997, 18, 3289-3295. [CrossRef]

25. Loveland, T.R.; Reed, B.C.; Brown, J.F.; Ohlen, D.O.; Zhu, Z.; Yang, L.; Merchant, J.W. Development of a global land cover characteristics database and IGBP DISCover from $1 \mathrm{~km}$ AVHRR data. Int. J. Remote Sens. 2000, 21, 1303-1330. [CrossRef]

26. Townshend, J.R.G. Global data sets for land applications from the Advanced Very High Resolution Radiometer: An introduction. Int. J. Remote Sens. 1994, 15, 3319-3332. [CrossRef]

27. Kim, D.-H.; Sexton, J.O.; Townshend, J.R. Accelerated deforestation in the humid tropics from the 1990s to the 2000s. Geophys. Res. Lett. 2015, 42, 3495-3501. [CrossRef] [PubMed]

28. Stibig, H.-J.; Achard, F.; Carboni, S.; Raši, R.; Miettinen, J. Change in tropical forest cover of Southeast Asia from 1990 to 2010. Biogeosciences 2014, 11, 247-258. [CrossRef]

29. Mayaux, P.; Pekel, J.F.; Desclée, B.; Donnay, F.; Lupi, A.; Achard, F.; Clerici, M.; Bodart, C.; Brink, A.; Nasi, R.; et al. State and evolution of the African rainforests between 1990 and 2010. Philos. Trans. R. Soc. B Biol. Sci. 2013, 368, 20120300. [CrossRef] [PubMed]

30. Woodcock, C.E.; Allen, R.; Anderson, M.; Belward, A.; Bindschadler, R.; Cohen, W.; Gao, F.; Goward, S.N.; Helder, D.; Helmer, E.; et al. Free Access to Landsat Imagery. Science 2008, 320, 1011. [CrossRef] [PubMed]

31. Hansen, M.C.; Potapov, P.V.; Moore, R.; Hancher, M.; Turubanova, S.A.; Tyukavina, A.; Thau, D.; Stehman, S.V.; Goetz, S.J.; Loveland, T.R.; et al. High-Resolution Global Maps of 21st-Century Forest Cover Change. Science 2013, 342, 850-853. [CrossRef] [PubMed]

32. Shimada, M.; Itoh, T.; Motooka, T.; Watanabe, M.; Shiraishi, T.; Thapa, R.; Lucas, R. New global forest/non-forest maps from ALOS PALSAR data (2007-2010). Remote Sens. Environ. 2014, 155, $13-31$. [CrossRef]

33. Morley, P.J.; Donoghue, D.N.M.; Chen, J.-C.; Jump, A.S. Quantifying structural diversity to better estimate change at mountain forest margins. Remote Sens. Environ. 2019, 223, 291-306. [CrossRef]

34. Mahmood, A.R.J. Forest Change in the Mangroves of the Ganges-Brahmaputra Delta 1906-2014. Ph.D. Thesis, Durham University, Durham, UK, 2015.

35. Lindquist, E.J.; D’Annunzio, R.; Gerrand, A.; MacDicken, K.G.; Achard, F.; Beuchle, R.; Brink, A.; Eva, H.D.; Mayaux, P.; San-Miguel-Ayanz, J.; et al. Global Forest Land-Use Change 1990-2005; FAO Forestry Paper; Food and Agriculture Organization of the United Nations and European Commission Joint Research Centre: Rome, Italy, 2012. 
36. Gong, P.; Wang, J.; Yu, L.; Zhao, Y.; Zhao, Y.; Liang, L.; Niu, Z.; Huang, X.; Fu, H.; Liu, S.; et al. Finer resolution observation and monitoring of global land cover: First mapping results with Landsat TM and ETM+ data. Int. J. Remote Sens. 2013, 34, 2607-2654. [CrossRef]

37. Sexton, J.O.; Song, X.-P.; Feng, M.; Noojipady, P.; Anand, A.; Huang, C.; Kim, D.-H.; Collins, K.M.; Channan, S.; DiMiceli, C.; et al. Global, 30-m resolution continuous fields of tree cover: Landsat-based rescaling of MODIS vegetation continuous fields with lidar-based estimates of error. Int. J. Digit. Earth 2013, 6, 427-448. [CrossRef]

38. Kim, D.-H.; Sexton, J.O.; Noojipady, P.; Huang, C.; Anand, A.; Channan, S.; Feng, M.; Townshend, J.R. Global, Landsat-based forest-cover change from 1990 to 2000. Remote Sens. Environ. 2014, 155, 178-193. [CrossRef]

39. UNFCCC. Addendum. Part two: Action taken by the Conference of the Parties. In Proceedings of the Report of the Conference of the Parties on its seventh session, Marrakesh, Morocco, 29 October-10 November 2001; Volume I, p. 69.

40. Herold, M.; Woodcock, C.E.; Mayaux, P.; Belward, A.S.; Latham, J.; Schmullius, C.C. A joint initiative for harmonization and validation of land cover datasets. IEEE Trans. Geosci. Remote Sens. 2006, 44, 1719-1727. [CrossRef]

41. Olofsson, P.; Foody, G.M.; Herold, M.; Stehman, S.V.; Woodcock, C.E.; Wulder, M.A. Good practices for estimating area and assessing accuracy of land change. Remote Sens. Environ. 2014, 148, 42-57. [CrossRef]

42. Foody, G.M. Assessing the accuracy of land cover change with imperfect ground reference data. Remote Sens. Environ. 2010, 114, 2271-2285. [CrossRef]

43. Powell, R.L.; Matzke, N.; de Souza, C.; Clark, M.; Numata, I.; Hess, L.L.; Roberts, D.A. Sources of error in accuracy assessment of thematic land-cover maps in the Brazilian Amazon. Remote Sens. Environ. 2004, 90, 221-234. [CrossRef]

44. Sannier, C.; McRoberts, R.E.; Fichet, L.-V. Suitability of Global Forest Change data to report forest cover estimates at national level in Gabon. Remote Sens. Environ. 2016, 173, 326-338. [CrossRef]

45. Bos, A.B.; Sy, V.; de Duchelle, A.E.; Herold, M.; Martius, C.; Tsendbazar, N.-E. Global data and tools for local forest cover loss and REDD+ performance assessment: Accuracy, uncertainty, complementarity and impact. Int. J. Appl. Earth Obs. Geoinf. 2019, 80, 295-311. [CrossRef]

46. Stehman, S.V.; Czaplewski, R.L. Design and Analysis for Thematic Map Accuracy Assessment: Fundamental Principles. Remote Sens. Environ. 1998, 64, 331-344. [CrossRef]

47. Cochran, W.G. Sampling Techniques, 3rd ed.; Wiley series in probability and mathematical statistics; Wiley: New York, NY, USA, 1977.

48. Donoghue, D.N.M.; Galiatsatos, N. Accuracy Assessment Report Year 7 Guyana REDD+ MRVS. 2018. Available online: https://www.forestry.gov.gy/wp-content/uploads/2018/11/Accuracy-Assessment-GuyanaMRVS-Year-7.pdf (accessed on 7 September 2019).

49. Magdon, P.; Fischer, C.; Fuchs, H.; Kleinn, C. Translating criteria of international forest definitions into remote sensing image analysis. Remote Sens. Environ. 2014, 149, 252-262. [CrossRef]

50. Tyukavina, A.; Stehman, S.V.; Potapov, P.V.; Turubanova, S.A.; Baccini, A.; Goetz, S.J.; Laporte, N.T.; Houghton, R.A.; Hansen, M.C. National-scale estimation of gross forest aboveground carbon loss: A case study of the Democratic Republic of the Congo. Environ. Res. Lett. 2013, 8, 044039. [CrossRef]

51. Bovolo, C.I.; Donoghue, D.N.M. Has regional forest loss been underestimated? Environ. Res. Lett. 2017, 12, 111003. [CrossRef]

52. Broich, M.; Stehman, S.V.; Hansen, M.C.; Potapov, P.; Shimabukuro, Y.E. A comparison of sampling designs for estimating deforestation from Landsat imagery: A case study of the Brazilian Legal Amazon. Remote Sens. Environ. 2009, 113, 2448-2454. [CrossRef]

53. Pickering, J.; Stehman, S.V.; Tyukavina, A.; Potapov, P.; Watt, P.; Jantz, S.M.; Bholanath, P.; Hansen, M.C. Quantifying the trade-off between cost and precision in estimating area of forest loss and degradation using probability sampling in Guyana. Remote Sens. Environ. 2019, 221, 122-135. [CrossRef]

54. Stehman, S.V. Model-assisted estimation as a unifying framework for estimating the area of land cover and land-cover change from remote sensing. Remote Sens. Environ. 2009, 113, 2455-2462. [CrossRef]

55. Stehman, S.V. Impact of sample size allocation when using stratified random sampling to estimate accuracy and area of land-cover change. Remote Sens. Lett. 2012, 3, 111-120. [CrossRef]

56. McRoberts, R.E.; Walters, B.F. Statistical inference for remote sensing-based estimates of net deforestation. Remote Sens. Environ. 2012, 124, 394-401. [CrossRef] 
57. Olofsson, P.; Foody, G.M.; Stehman, S.V.; Woodcock, C.E. Making better use of accuracy data in land change studies: Estimating accuracy and area and quantifying uncertainty using stratified estimation. Remote Sens. Environ. 2013, 129, 122-131. [CrossRef]

58. Stehman, S.V. Selecting and interpreting measures of thematic classification accuracy. Remote Sens. Environ. 1997, 62, 77-89. [CrossRef]

59. Friedl, M.A.; McIver, D.K.; Hodges, J.C.F.; Zhang, X.Y.; Muchoney, D.; Strahler, A.H.; Woodcock, C.E.; Gopal, S.; Schneider, A.; Cooper, A.; et al. Global land cover mapping from MODIS: Algorithms and early results. Remote Sens. Environ. 2002, 83, 287-302. [CrossRef]

60. Milodowski, D.T.; Mitchard, E.T.A.; Williams, M. Forest loss maps from regional satellite monitoring systematically underestimate deforestation in two rapidly changing parts of the Amazon. Environ. Res. Lett. 2017, 12, 094003. [CrossRef]

61. Asner, G.P.; Llactayo, W.; Tupayachi, R.; Luna, E.R. Elevated rates of gold mining in the Amazon revealed through high-resolution monitoring. Proc. Natl. Acad. Sci. USA 2013, 110, 18454. [CrossRef]

62. MacDicken, K.G. Global Forest Resources Assessment 2015: What, why and how? For. Ecol. Manag. 2015, 352, 3-8. [CrossRef]

(C) 2020 by the authors. Licensee MDPI, Basel, Switzerland. This article is an open access article distributed under the terms and conditions of the Creative Commons Attribution (CC BY) license (http://creativecommons.org/licenses/by/4.0/). 